\title{
Soviet worries about nuclear safety after Chernobyl
}

\section{London}

Plans for the Chernobyl nuclear power station have been changed, Soviet television news announced last week. The original plans for the rehabilitation of the power station after the disaster included not only the recommissioning of Blocks 1 and 3 , but also the completion of blocks 5 and 6 , which were under construction at the time of the accident. Now, however, it has been decided to dismantle blocks 5 and 6 instead.

This is not entirely surprising. In March 1986, a month before the accident, the weekly Literaturna Ukrayina carried an alarming account of skimped work and corner cutting in the construction of block 5. Last week's decision seems to have been based, however, not on the possible defects on blocks 5 and 6 but on the whole issue of the safety of the RBMK reactor. After the disaster, the Soviet nuclear energy authorities committed themselves to phase out the RBMK programme, and to introduce additional safety systems on those reactors already in service. During the past two years, however, public anxiety about the RBMK has grown. Moreover, it has now emerged that, from the very beginning, some Soviet scientists had considerable doubts about the safety of the RBMK, but were overruled by the "scientific councils" in charge of decisionmaking. "Dissenting opinions required", should be written over the doors of all nuclear power institutes, commented Literaturnaya Gazeta two weeks ago.

Public concern over nuclear safety is not always matched with glasnost. In Ukraine, where there is, not surprisingly, a high incidence of 'radiophobia', a new type of bread will soon be launched which, it is claimed, contains chemicals that will help to eliminate radioactive strontium and caesium from the body, and the appropriations for research into the effect of radioisotopes on the human organism has just been doubled by the Ukrainian Council of Ministers; developments which cause many people to doubt official assurances that the 600,000 people examined so far from the Kiev and Chernobyl areas have shown only "insignificant" levels of strontium and caesium-137. Public pressure against the building of a nuclear power station at Chyhyryn on the Dnieper resulted in its official cancellation - but, the Secretary of the Ukrainian Writers' Union, Borys Oleynyk, warned recently, construction still seems to be going on.

In Lithuania, a fire at the Ignalina RBMK power station on 20 July caused much local anxiety. The fire proved to be a relatively small one, and none of the reactors was affected, but, the station manage- ment has been criticized by local officials and the Party daily Tiesa for making no announcement for five days.

And in Poland, which was also affected by Chernobyl fallout, the inhabitants of Warsaw are much concerned about a new Soviet-Polish agreement to carry out nuclear accident simulations at Swierk, only a few kilometres from the city centre. An ageing research reactor is to be adapted for the purpose, although the scientist in charge, Dr Andrzej Strupczewski, admitted to reporters that it would probably have been easier to build a full-scale power plant. The facility, the inhabitants of Warsaw note nervously, will be only the third in the world capable of simulating a "maximum projected breakdown". The other two - one in the United States and one French, are sited respectively in the desert and underground.

Vera Rich

\section{Political stalemate over IVF finally broken in Australia}

\section{Sydney}

THE political stalemate that halted activity by one of the world's top in-vitro fertilization (IVF) research groups has finally been broken. Alan Trounson's group at the Centre for Early Human Development, based in Melbourne's Queen Victoria Hospital, has received permission to create 80 embryos to use in tests for chromosomal defects that might occur in fertilization by the micro-injection of single sperm. Permission was granted by the Victoria state government's Standing Review and Advisory Committee on Infertility, chaired by Professor Louis Waller. The Waller committee has been deadlocked over whether to let the experiment go ahead since late 1986. The breakthrough came last month when the Victoria state parliament clarified its IVF law by finally proclaiming an outstanding section of the original legislation that allows the creation of embryos for research.

In the present experiment, the embryos must be tested within 20 hours of fertilization, just before the fusion of genetic

\section{Save the trees}

\section{Washington}

IN the tradition of Live Aid and the recent 'Freedomfest', rock musician and actor Sting has joined forces with the World Wildlife Fund (WWF), the Smithsonian Institution and British schoolchildren to produce Yanomamo, a musical which will benefit the preservation of the world's tropical rainforests and aid the people of those areas. The first US performance was held last month at the Kennedy Center in Washington.

Yanomamo is a musical exploration of the problems in the Amazon Basin and a celebration of its richness and beauty. Sting hosted and narrated and the children played and sang the production. Proceeds from the event benefit WWF and the Institute for Sustainable Development, two groups devoted to conservation of tropical tracts.

Lisa Lyles material from the sperm and egg occurs.

Microinjection involves placing a single sperm on the tip of an ultra-fine needle and injecting it through the outer wall of an egg. The technique offers new hope to men who are infertile due to the inability of their sperm to penetrate the egg, perhaps because of malformation of the sperm.

Research with mice has shown no increased risk of abnormalities using microinjection. In fact, several couples were provided with the microinjection treatment by a team lead by Professor Carl Wood of Monash University. But the technique was then banned by the Victoria Minister for Health, pending assessment by the Waller committee. Similar techniques are already being used in the United States and Europe, although Trounson claims they have not reached his group's technical level.

The neighbouring state of New South Wales does not have any legislation corresponding to the Victoria IVF law. Trounson has collaborated with researchers there to test the microinjection technique at a private IVF clinic in Sydney, using sperm and eggs donated by 16 couples. The research was carried out under guidelines laid down by the National Health and Medical Research Council in 1982 and with the approval of the Ethics Review Committee at the Royal Prince Alfred Hospital.

The conduct of the tests in Sydney has led to calls for uniform federal regulations on IVF research. The NSW Law Reform Commission is at present examining the question of IVF and is expected to release a report shortly.

The number of embryos used in the Sydney experiments will be subtracted from the 80 to be tested by Trounson in Melbourne. $\mathrm{He}$ is not satisfied with the figure of 80 , which was considered the minimum number that could yield meaningful results. Trounson says that the 80 will be enough to detect any dramatic increase in chromosomal abnormalities but the experiment might not pick up more subtle defects. 